Viktoriia Kovalchuk, Ph. D., Associate Professor

(Associate Professor of Department of theoretical and applied mechanics, State University of Infrastructure and Technologies)

\title{
BIFURCATION ANALYSIS OF THE STABILITY OF ONE DYNAMICAL SYSTEM WITH A FOLLOWER FORCE
}

In this paper, for an inverted double pendulum with asymmetric follower force a mathematical model has been constructed in generalized coordinates. The dynamics of the system has been explored through both analytical and numerical approaches. Stability diagrams have been presented. The influence of the follower forces parameters on the dynamical behavior of the pendulum has been analyzed. Numerical simulation has been applied to obtain integral curves and phase portraits. The trajectories of the lower and upper poles of the pendulum have been constructed too.

Keywords: dynamical system, inverted double pendulum, follower force, stability.

\section{Introduction}

Many researchers have studied the dynamic of pendulum systems. An inverted double pendulum is a combination of two individual pendulums which represents an example of a nonlinear and unstable dynamic system. This model is currently actively used for research and experiments in such fields as automatic aircraft landing system, biped locomotive machines, in robotics, aerospace, marine vehicles, etc. An inverted pendulum with a follower force simulates the structural elements of the props of railway bridges, track-laying machines, and other structures.

An inverted pendulum is a popular benchmark problem in control theory too. The main reason for this is that it constitutes a nonlinear system with unstable and nonminimum-phase behavior and thus reveals many interesting system-theoretic properties

Although the pendulum systems have widely used in engineering, the qualitative behavior these systems has not been investigated enough. Bifurcation analysis allows revealing special modes of functioning of the corresponding mechanical systems. The study of the peculiarities of the dynamic behavior of the indicated pendulum makes it possible to optimize its parameters in order to avoid violations of the normal conditions of the functioning of the corresponding mechanical systems and to ensure the strength and stability of its elements.

\section{Analysis of recent research and problem statement}

Studying the oscillations of multilink inverted pendulums is a task of current importance in theoretical mechanics. This is a favorite example of a system for demonstration at lectures by students and faculty of physics, dynamics, and theory of

DOI: 10.32703/2617-9040-2019-33-2-4

Збірник наукових праць ДУІТ. Серія «Транспортні системи і технологї̈, 2019. Вип.33. Т.2 
control [1]. A dynamics of the inverted pendulum are similar to many real-world systems, for instance, in robotics, for modeling of human walking, Segway, biped locomotive machines, flexible space structures, and many more industrial applications [2, 3]. For solving the problems of balancing rockets during vertical take-off investigate the stability of the rotary inverted pendulum. It is also a very good model for an automatic aircraft landing system, aircraft stabilization in the turbulent air-flow, stabilization of a cabin in a ship, etc. $[4,5]$.

A double inverted pendulum on a cart is a popular benchmark problem in control theory. This system in control laboratories is widely used as a benchmark for testing control algorithms [6, 7]. The main reason for this is that it constitutes a nonlinear system with unstable and nonminimum-phase behavior and thus reveals many interesting systemtheoretic properties $[8,9]$.

In theoretical mechanics, it is important to study the behavior of inverted multilink pendulums with an elastically secured upper end, to which the follower force is applied. Such a model simulates the structural elements of the pillars of railway buildings and bridges. The inverted mathematical pendulum with a follower force is designed too to study the dynamic stability of the cantilever tube that conducts a moving fluid. The first works of this cycle were initiated by the problems of the functioning of oil pipelines [10, 11]. Later, Japanese scientists, when examining the Ziegler's double inverted pendulum, supplemented the model with asymmetry of the follower force [1].

In $[12,13]$ author presents a study of the optimal mass distribution in a classical Ziegler's pendulum where local and global extrema can be found explicitly. In the article, proposed to consider an m-link Ziegler-Lobas pendulum loaded by a follower force as a model problem for studying the basic properties of optimization of circulatory systems with respect to stability criteria.

In recent years, there has been particular interest in the bifurcation analysis of nonlinear behavior of inverted pendulums with follower force [14]. Analytical calculations and numerical modeling show that sequential force is the controlling factor in the dynamic behavior of the system. From the standpoint of the qualitative theory of differential equations, this force is a bifurcation parameter on whose values the behavior (stable or unstable) of the model depends. In contrast to conservative systems, the inverted pendulum with a follower force is a non-conservative system that can lose stability both by divergence and by flutter.

In this paper, the dynamic behavior of a double-pendulum system near critical points is investigated both through analytic and numerical approaches. Two critical cases of Lyapunov's theory of stability are considered, which are characterized by one zero eigenvalues and a pair of purely imaginary eigenvalues. In the first case, the divergent bifurcation occurs in the phase space of the pendulum. In the second case, we have a flutter bifurcation.

Bifurcations in the phase space of a double inverted pendulum with a follower force are determined by nonlinear dynamics. Our aim is to understand these dynamics in a qualitative way, with a special interest in stability. All analytical results are verified using the symbolic language of the Maple calculations. It is shown that all numerical solutions agree with the analytic prediction, at least qualitatively.

\section{The purpose and tasks of the study}

The purpose of the work is to use the means of the theory of dynamic systems for bifurcation analysis of the peculiarities of the behavior of an inverted double pendulum with a follower force on the upper end. 


\section{Mathematical modelling of an inverted pendulum system (in generalized coordinates)}

The double inverted pendulum system consists of two rigid weightless links of length $l_{1}$ and $l_{2}$ that carry two concentrated masses $m_{1}$ and $m_{2}$, respectively. The pendulum is attached to a firm basement by a viscoelastic revolute joint with the stiffness coefficient $c_{1}$ and the damping coefficient $\mu_{1}$. Another viscoelastic revolute joint with the stiffness coefficient $c_{2}$ and the damping coefficient $\mu_{2}$ connects the two rods.

The positions of the pendulum's lower and upper poles respectively are given by:

$$
\left[\begin{array}{l}
x_{1} \\
y_{1}
\end{array}\right]=\left[\begin{array}{l}
l_{1} \cos \left(\varphi_{1}\right) \\
l_{1} \sin \left(\varphi_{1}\right)
\end{array}\right], \quad\left[\begin{array}{l}
x_{2} \\
y_{2}
\end{array}\right]=\left[\begin{array}{l}
x_{1}+l_{2} \cos \varphi_{2} \\
y_{1}+l_{2} \sin \varphi_{2}
\end{array}\right],
$$

where $\varphi_{1}$ and $\varphi_{2}$ are the generalized coordinates (the angular displacements measured from the vertical).

A follower force $\vec{P}$, generally asymmetric, is applied to the upper pole of the pendulum. Asymmetry of this force determine the angle eccentricity $\delta=$ const and orientation parameter $k=$ const. The direction of action of the force $\vec{P}$ varies depending on the change in the configuration of the mechanical system, caused by this force. The presence of a follower force makes the dynamical system under study non-conservative.

To achieve a mathematical description, system behavior is described by Lagrange's equations:

$$
\frac{d}{d t} \frac{\partial T(\varphi, \dot{\varphi})}{\partial \dot{\varphi}_{j}}-\frac{\partial T(\varphi, \dot{\varphi})}{\partial \varphi_{j}}=Q_{j}(\varphi, \dot{\varphi}), \quad j=1,2 .
$$

where $T(\varphi, \dot{\varphi})$ - kinetic energy of the system, $\varphi=\left[\varphi_{1}, \varphi_{2}\right]^{T}-$ the vector-column of the generalized coordinates.

The method begins by writing down the kinetic energy $T$ of the system. This energy consists of a two component (for the lower and upper poles of the pendulum):

$$
T=T_{1}+T_{2}=\frac{m_{1}}{2}\left(\dot{x}_{1}^{2}+\dot{y}_{1}^{2}\right)+\frac{m_{2}}{2}\left(\dot{x}_{2}^{2}+\dot{y}_{2}^{2}\right) .
$$

According to formulas (1) the total energy of the system in generalized coordinates is:

$$
T=\frac{1}{2}\left(m_{1}+m_{2}\right) l_{1}^{2} \dot{\phi}_{1}^{2}+\frac{1}{2} m_{2} l_{2}^{2} \dot{\phi}_{2}^{2}+m_{2} l_{1} l_{2} \dot{\phi}_{1} \dot{\phi}_{2} .
$$

Then Lagrange equations (2) for the inverted pendulum can be written in a more compact matrix form:

$$
M(\varphi) \cdot \ddot{\varphi}=C(\varphi, \dot{\varphi}) \cdot \dot{\varphi}+G(\varphi) .
$$

Here $M$ is a matrix of mass: 


$$
M=\left|\begin{array}{cc}
\left(m_{1}+m_{2}\right) l_{1}^{2} & m_{2} l_{1} l_{2} \cos \left(\phi_{1}-\phi_{2}\right) \\
m_{2} l_{1} l_{2} \cos \left(\phi_{1}-\phi_{2}\right) & m_{2} l_{2}^{2}
\end{array}\right| .
$$

Therefore, the equation (3) is the dynamic equations for a mechanical system with 2 degrees of freedom.

Next, we use the parameters of the lower link $\left(m_{1}, l_{1}, c_{1}\right)$ as the base and introduce the dimensionless time:

$$
\tau=t \cdot \frac{\sqrt{c_{1}}}{l_{1} \sqrt{m_{1}}} .
$$

Dimensionless quantities of the pendulum marking with overbars: $\bar{P}$ is a dimensionless module of the follower force, $\bar{c}$ is dimensionless stiffness of the horizontal spring at the upper pole of the pendulum. We consider these two parameters as the essential parameters of the studied system. At different values of essential parameters, we observe various patterns of motion of the studied dynamic system.

The linear model of the triple link inverted pendulum is represented in state-space form as follows:

$$
\ddot{x}=A \cdot x+B .
$$

Here $x=\left[x_{1}, x_{2}, x_{3}, x_{4}\right]^{T}=\left[\varphi_{1}, \dot{\varphi}_{1}, \varphi_{2}, \dot{\varphi}_{2}\right]^{T}-$ the vector-column of the variables state of system.

The eigenvalues associated with matrix $A$ of the linearized differential equations (4) determine the stability of the position of the equilibrium of the pendulum. We will denote the dimensionless value of the follower force through $P_{d}$ if one eigenvalue of the matrix $A$ is zero. If the pair of eigenvalues is purely imaginary, then we denote the module of the force $P_{f}$. The symbols are associated with divergent and flutter bifurcations. For values $P_{d}$ and $P_{f}$ we have critical cases of the Lyapunov's stability theory.

When the image point of the system passes through the $P_{d}$ boundary, the divergent bifurcation occurs. In the phase space of the pendulum, the point $x=0$ loses its stability, but another stable point appears. The pendulum has a non-vertical equilibrium position.

When the image point of the system passes through the $P_{f}$ boundary, the Hopf bifurcation occurs. The vertical equilibrium position of the pendulum $\left(\varphi_{1}=0, \varphi_{2}=0\right)$ loses its stability, the periodic solution of the equations (3) appears. In the phase space of the pendulum, for this periodic solution corresponds to the limit cycle (stable or unstable). For the pendulum we have oscillatory motion.

\section{Simulation results}

After obtaining the mathematical model of the system, we need to analyze the stability of the system in order to further understand the features of the system. Here we carried out some numerical simulations using the Maple system. Numerical simulation is carried out for an inverted double pendulum with the parameters specified in Table 1. 
Table 1. List of Parameters for the double pendulum

\begin{tabular}{|c|l|c|}
\hline Symbol & Description & Value/Unit \\
\hline$m_{1}$ & mass of the first pole & $10 \mathrm{~kg}$ \\
\hline$m_{2}$ & mass of the second pole & $5 \mathrm{~kg}$ \\
\hline$l_{1}$ & length of the lower rod & $0,5 \mathrm{~m}$ \\
\hline$l_{2}$ & length of the upper rod & $0,5 \mathrm{~m}$ \\
\hline$c_{1}$ & $\begin{array}{l}\text { stiffness coefficient of the lower } \\
\text { spiral springs (in the joints } O \text { ) }\end{array}$ & $400 \mathrm{~N} \cdot \mathrm{m}$ \\
\hline$c_{2}$ & $\begin{array}{l}\text { stiffness coefficient of the upper } \\
\left.\text { spiral springs (in the joints } A_{1}\right)\end{array}$ & $400 \mathrm{~N} \cdot \mathrm{m}$ \\
\hline$g$ & acceleration due to gravity & $9,81 \mathrm{~m} / \mathrm{s}^{2}$ \\
\hline
\end{tabular}

Fig. 1 shows the stability diagram for the double pendulum. The domain $D(4,0)$ is an asymptotic stability domain in which the matrix $A$ of equation (4) has 4 eigenvalues $\lambda_{i}$ with negative real parts.

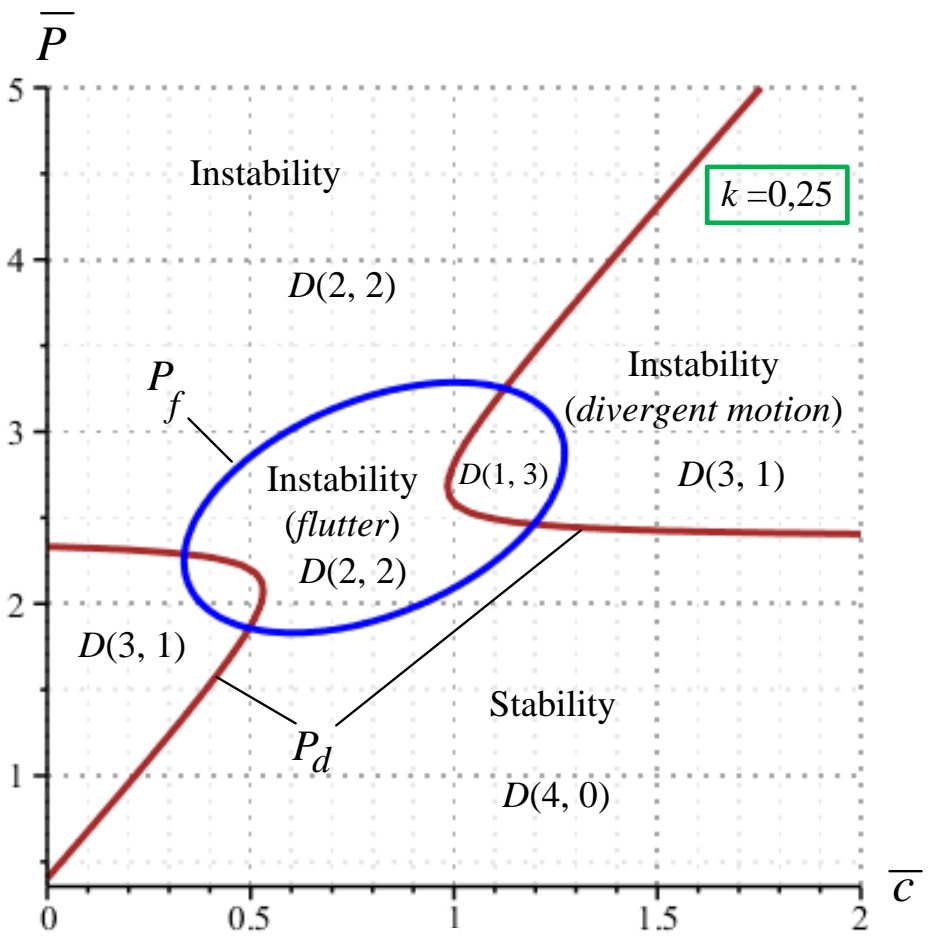

Figure 1. Stability diagram for double pendulum $(k=0,25)$ 
In the domain $D(s, 4-s)$ we have $s$ eigenvalues with $\operatorname{Re} \lambda_{i}<0$. The change of the eigenvalues of the matrix $A$ in the change of the essential parameter $\bar{P}$ of the pendulum is given in Table 2 .

Table 2. Eigenvalues (the double pendulum with $\boldsymbol{k}=\mathbf{0 , 2 5}, \bar{c}=\mathbf{1 , 5}$ )

\begin{tabular}{|c|c|c|c|c|c|}
\hline $\bar{P}$ & $\lambda_{1}$ & $\lambda_{2}$ & $\lambda_{3}$ & $\lambda_{4}$ & \multirow{2}{*}{ Domain } \\
\hline 1,0 & $-0,98+1,80 i$ & $-0,98-1,80 i$ & $-0,12+1,31 i$ & $-0,12-1,31 i$ & \multirow{2}{*}{$D(4,0)$} \\
\hline 2,0 & $-1,01+0,41 i$ & $-1,01-0,41 i$ & $-0,10+1,17 i$ & $-0,10-1,17 i$ & \\
\hline 2,5 & 0,03 & $-2,14$ & $-0,05+1,05 i$ & $-0,05-1,05 i$ & \multirow{2}{*}{$D(3,1)$} \\
\cline { 1 - 5 } 3,0 & 0,51 & $-2,67$ & $-0,02+0,89 i$ & $-0,02-0,89 i$ & \multirow{2}{*}{$D$} \\
\cline { 1 - 5 } 4,0 & 1,24 & $-3,40$ & $-0,03+0,45 i$ & $-0,03-0,45 i$ & \\
\hline 4,5 & 1,53 & $-3,69$ & 0,20 & $-0,26$ & $D(2,2)$ \\
\hline
\end{tabular}

At dimensionless stiffness $\bar{c}=1.1$ of the horizontal spring at the upper pole of the pendulum, the more complex change in the eigenvalues of matrix $A$ is shown in Table 3 .

Table 3. Eigenvalues (the double pendulum with $\boldsymbol{k}=\mathbf{0 , 2 5}, \bar{c}=\mathbf{1 , 1}$ )

\begin{tabular}{|c|c|c|c|c|c|}
\hline $\bar{P}$ & $\lambda_{1}$ & $\lambda_{2}$ & $\lambda_{3}$ & $\lambda_{4}$ & Domain \\
\hline 1,0 & $-0,08+1,11 i$ & $-0,08-1,11 i$ & $-1,03+1,73 i$ & $-1,03-1,73 i$ & \multirow{3}{*}{$D(4,0)$} \\
\hline 2,0 & $-0,03+0,88 i$ & $-0,03-0,88 i$ & $-1,07+1,30 i$ & $-1,07-1,30 i$ & \\
\hline 2,2 & $-0,01+0,81 i$ & $-0,01-0,81 i$ & $-0,44$ & $-1,75$ & \\
\hline 2,3 & $0,01+0,78 i$ & $0,01-0,78 i$ & $-0,28$ & $-1,94$ & \multirow{2}{*}{$D(2,2)$} \\
\hline 2,5 & $0,02+0,69 i$ & $0,02-0,69 i$ & $-0,04$ & $-2,22$ & \\
\hline 2,6 & $0,03+0,63 i$ & $0,03-0,63 i$ & 0,06 & $-2,34$ & \multirow{3}{*}{$D(1,3)$} \\
\hline 2,8 & $0,04+0,51 i$ & $0,04-0,51 i$ & 0,25 & $-2,55$ & \\
\hline 3,2 & $0,01+0,14 i$ & $0,01-0,14 i$ & 0,66 & $-2,90$ & \\
\hline 3,3 & 0,17 & $-0,17$ & 0,76 & $-2,97$ & \multirow{3}{*}{$D(2,2)$} \\
\hline 3,5 & 0,34 & $-0,36$ & 0,93 & $-3,12$ & \\
\hline 4,0 & 0,57 & $-0,63$ & 1,29 & $-3,45$ & \\
\hline
\end{tabular}

In this case, the image point of the system first passes through the boundary $P_{f}$ of the stability domain and enters the domain $D(2,2)$ of flutter instability from domain $D(4,0)$ asymptotic stability. Next, the image point passes through the boundary of $P_{d}$ and passes to the domain $D(1,3)$. After this, the point again passes through the boundary of $P_{d}$ and falls into domain $D(2,2)$. 
In Fig. 2 influence of the follower forces orientation parameter $k$ on the system's stability is represented. As the magnitude of $k$ increases, the domain $D(2,2)$ of the flutter instability extends. The curve $P_{f}$, which corresponds to a pair of purely imaginary eigenvalues of matrix $A$, limits this domain.

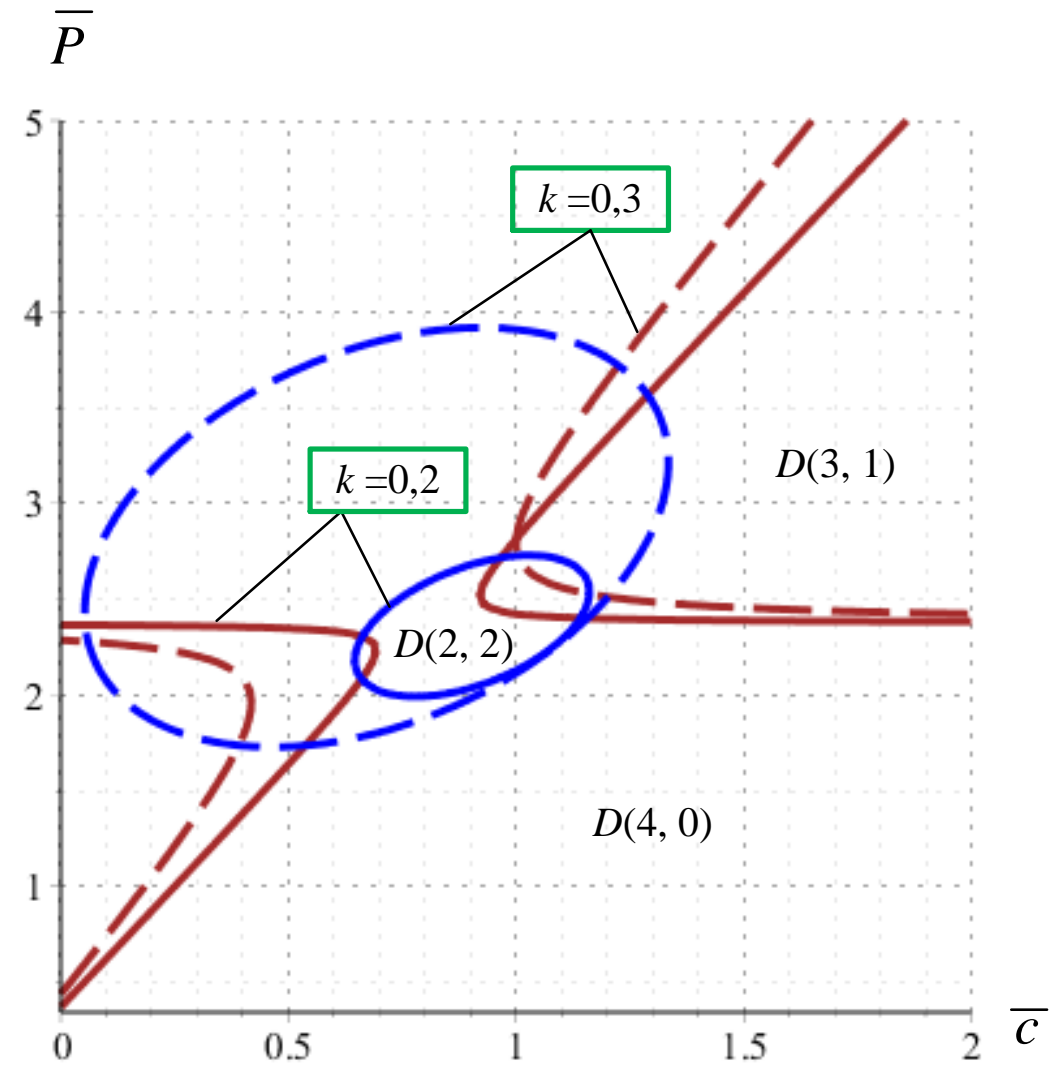

Figure 2. Influence of the orientation parameter $k$ on the stability diagram

On the boundary of $P_{f}$ of the domain of stability, there is a bifurcation of Poincare Andronov - Hopf. The vertical position of the equilibrium of the pendulum is lost due to the birth of the boundary cycle. Fig. 3 shows a stable boundary cycle that limits the region of attraction of the phase trajectories of the pendulum. The phase portrait and time profile in Fig. 3 are constructed with the supercritical value $\bar{P}=2.3>P_{f}$ of the follower force module. The initial conditions of motion given by:

$$
\left[\varphi_{1}=0.1, \dot{\varphi}_{1}=0.05, \varphi_{2}=0.2, \dot{\varphi}_{2}=0.05\right] \text {. }
$$

The starting point of the integration of the system of the differential equations (4) in Fig. 3 is denoted by $S$. Over time, the image point of the system goes away from the origin and goes to a stable boundary cycle. A phase trajectory constructed in space 
$\left[t, \varphi_{2}, \dot{\varphi}_{2}\right]$ more clearly demonstrates the behavior of the system (Fig. 3, $b$ ). Curves on

Fig. 3 are constructed for the angle $\varphi_{2}$, which characterizes the position of the upper pole of the pendulum. For the lower pole the corresponding curves have a similar configuration.

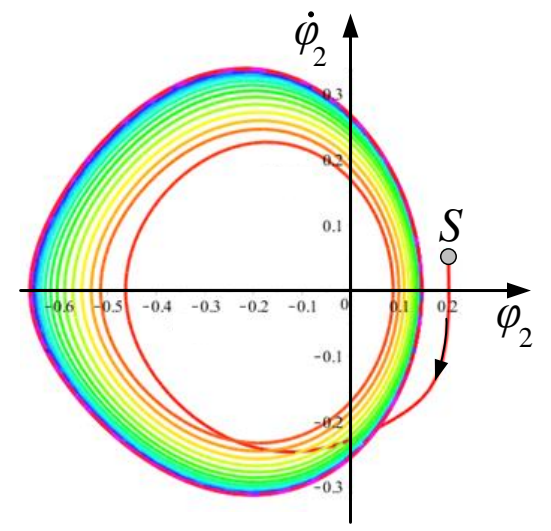

a)

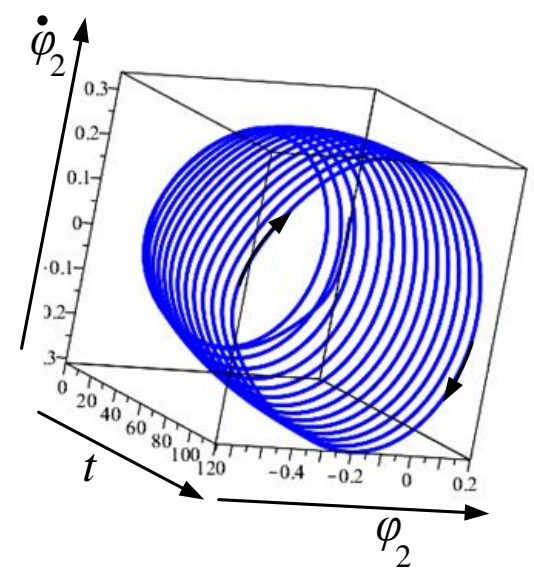

b)

Figure 3. Phase portraits (a) and time profile

(b) in the case domain $\boldsymbol{D}(\mathbf{2 , 2})$

The asymmetry of the follower force has a strong influence on the stability and the bifurcation of the system. Fig. 4 shows how the angular eccentricity $\delta$ of the force $\vec{P}$ affects the angles of deviation of the pendulum links from the vertical.

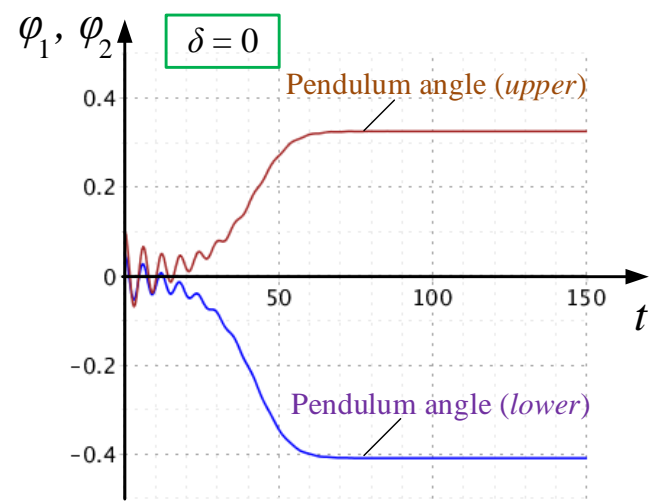

a)

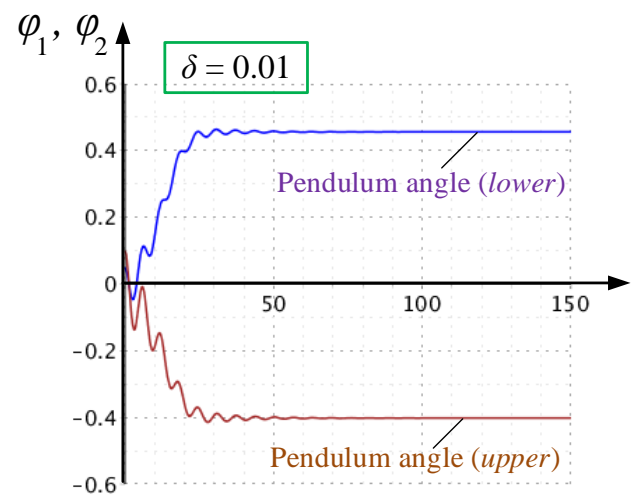

b)

Figure 4. Simulation curves of state variables in the case domain $\boldsymbol{D}(\mathbf{3 , 1})$ :

a) for $\boldsymbol{\delta}=\mathbf{0}, b)$ for $\boldsymbol{\delta}=\mathbf{0 . 0 1}$

The trajectories of the lower and upper poles of the pendulum are shown in Fig. 5. They allow you to get more information about changing the position of the pendulum links over time. 


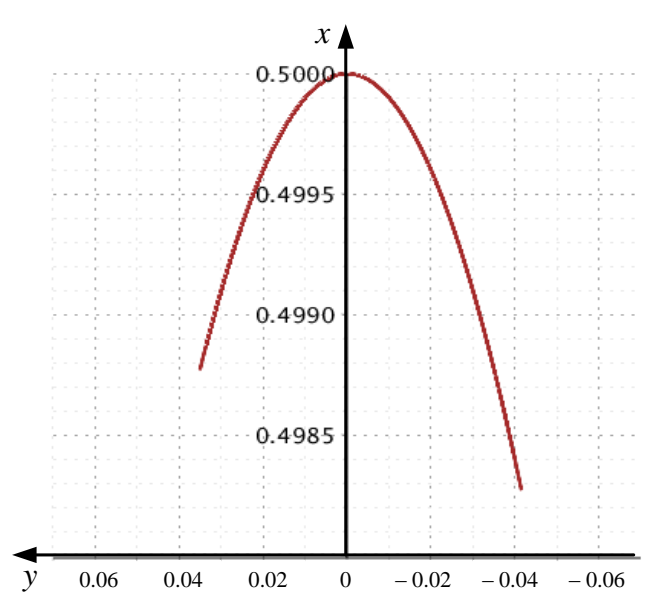

a)

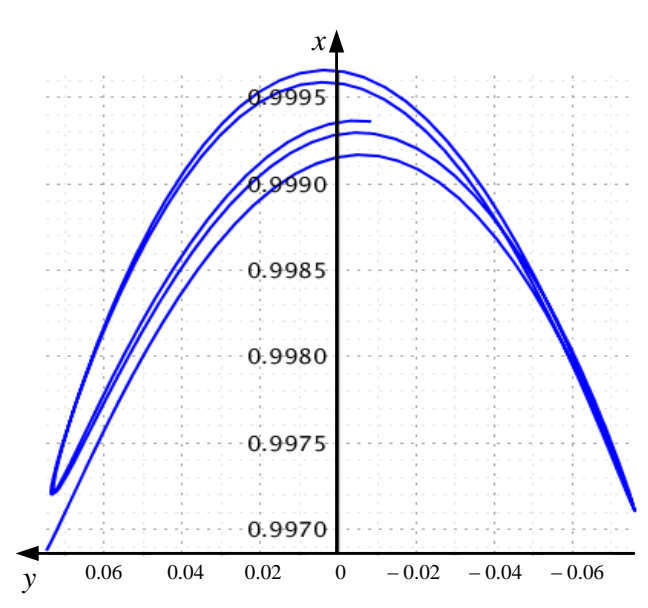

b)

Fig. 5. Trajectories of the poles of the double pendulum:

a) lower poles, $b$ ) upper poles

To fully analyze the behavior of the pendulum, it is still necessary to identify safe and dangerous areas of the boundary of the stability domain. A task of current importance in the qualitative analysis of a double pendulum is to study the behavior of the solutions near the asymptotic stability boundaries in the first approximation because this behavior determines the mechanisms whereby the pendulum loses stability in equilibrium positions. As termed in $[14,15]$, the stability boundary of an equilibrium state is safe if the stability is asymptotic in a critical case and dangerous if not asymptotic. Physically, a safe asymptotic-stability boundary means soft loss of stability. In this case, stable oscillations (limit cycles) occur instead of asymptotically stable equilibrium. If a dangerous stability boundary is approached by a representative point of the system moving within the stability domain, the equilibrium state will practically lose stability, though equilibrium state is asymptotically stable in the sense of Lyapunov from the formal-mathematical point of view.

\section{Conclusions}

In the present study, using Lyapunov's stability theory, features of the dynamical behavior of an inverted pendulum with follower force were investigated. By means of the theory of dynamical systems, a bifurcation analysis of the pendulum's behavior peculiarities was made when the essential parameters of the system were changed. Numerical methods are used to study bifurcation cases. A specially developed Mapleprogram for determining Lyapunov values allows you to analyze the behavior of a dynamic system near the boundaries of stability domains. The study of the features of the dynamic behavior of the indicated pendulum makes it possible to optimize its parameters in order to avoid violations of the normal conditions of the functioning of the corresponding mechanical systems. 


\section{REFERENCES}

1. Lundberg K. H., \& Barton, T. W. (2010). History of inverted-pendulum systems. IFAC Proceedings Volumes, 42(24), 131-135.

2. Boubaker, O. (2017). The inverted pendulum: history and survey of open and current problems in control theory and robotics. The Inverted Pendulum in Control Theory and Robotics: From Theory to New Innovations, 111, 1 .

3. Moysis, L. (2016). Balancing a double inverted pendulum using optimal control and Laguerre functions. Aristotle University of Thessaloniki, Greece, 54124.

4. Mathew, N. J., Rao, K. K., \& Sivakumaran, N. (2013). Swing up and stabilization control of a rotary inverted pendulum. IFAC Proceedings Volumes, 46(32), 654-659.

5. Sultan, G. A., \& Farej, Z. K. (2017). Design and Performance Analysis of LQR Controller for Stabilizing Double Inverted Pendulum System.

6. Nalavade, M. R., Bhagat, M. J., \& Patil, V. V. (2014). Balancing Double Inverted Pendulum on A cart by Linearization Technique. International Journal of Recent Technology and Engineering (IJRTE), 3(1), 153-157.

7. Wu, S. M., Song, J. W., \& Zhang, W. Q. (2014). Optimal Control Theory Research on Inverted Pendulum System. In Applied Mechanics and Materials (Vol. 494, pp. 1118-1121). Trans Tech Publications.

8. Glück, T., Eder, A., \& Kugi, A. (2013). Swing-up control of a triple pendulum on a cart with experimental validation. Automatica, 49(3), 801-808.

9. Sharma, K., \& Sahu, V. (2016). Modeling and Stabilization of Cart Triple Link Inverted Pendulum using LQR Controller Incorporating Degree of Stability. International Research Journal of Advanced Engineering and Science, 1(4), 148-152.

10. Pflüger, A. (2013). Stabilitätsprobleme der Elastostatik. Springer-Verlag.

11. Ziegler, H. (2013). Principles of structural stability (Vol. 35). Birkhäuser.

12. Kirillov, O. N. (2010). Structural optimization of the Ziegler's pendulum: singularities and exact optimal solutions. arXiv preprint arXiv:1101.0246.

13. Kirillov, O. (2011). Re- visiting structural optimization of the Ziegler pendulum: singularities and exact optimal solutions. PAMM, 11(1), 717-718.

14. Nikolov, S., \& Nedev, V. (2016). Bifurcation analysis and dynamic behavior of an inverted pendulum with bounded control. Journal of Theoretical and Applied Mechanics, 46(1), 17-32.

15. Kuznetsov, Y. A. (2013). Elements of applied bifurcation theory (Vol. 112). Springer Science \& Business Media.

\section{ЛIТЕРАТУРА}

1. Лундберг К. Х., Бартон Т. В. Історія перевернутих маятникових систем. Праці МФАК. 2010. Вип. 42(24), С. 131-135.

2. Бубакер О. Перевернутий маятник: історія та огляд відкритих і сучасних проблем теорії управління та робототехніки. Перевернутий маятник в теорї управління і робототехніuі: від теорії до нових інновачій. 2017, 111, 1.

3. Мойзис Л. Балансування подвійного перевернутого маятника 3 використанням оптимального управління і функцій Лагерра. Університет Аристотеля в Салоніках, Греція. 2016. Технічний звіт IKEERPT-2016-005.

4. Метью Н. Дж., Рао К. К., Сивакумаран Н. Поворотний і стабілізаційний контроль ротаційного перевернутого маятника. Пращиі МФАК. 2013. Вип. 46(32), С. 654-659.

5. Султан Г. А., Фарей 3.K. Розробка та аналіз продуктивності LQR-контролера для стабілізації подвійної перевернутої маятникової системи. Циркуляція в комп ’отерних науках. 2017. Т. 2, № 9, C. $1-5$.

6. Налаваде М. Р., Бхагат М. Дж., Патил В. В. Балансування подвійного перевернутого маятника на візку методом лінеаризації. Міжнародний журнал сучасних технологій та інженерії. 2014 Вип. 3(1), С. 153-157.

7. Ву Ш. М., Сонг Дж. В., Чжан В. К. Дослідження оптимальної теорії керування системою перевернутого маятника. Прикладна механіка та матеріали. 2014. Т. 494, С. 1118-1121.

8. Глюк Т., Едер А., Кугі А. Поворотний контроль потрійного маятника на візку 3 експериментальною перевіркою. Автоматика. 2013. Вип. 49(3), С. 801-808.

Збірник наукових праць ДУІТ. Серія «Транспортні системи і технологї̈», 2019. Вип.33. Т.2 
9. Шарма К., Саху В. Моделювання та стабілізація потрійного перевернутого маятника на візку за допомогою контролера LQR, що має ступінь стійкості. Міжнародний науковий журнал передової інженерії та науки. 2016. Вип. 1(4), С. 148-152.

10. Пфлюгер А. Пробеми стійкості еластостатики. Берлін, Springer-Verlag, 2013. 473 с.

11. Циглер Х. Принципи структурної стійкості. Базель, Birkhäuser, 2013. 150 с.

12. Кирилов О. М. Структурна оптимізація маятника Циглера: особливості та точні оптимальні розв'язки. Асtа Політехніка. 2010. Вип. 51(4), С. 32-43.

13. Кирилов О. М. Повторне дослідження структурної оптимізації маятника Циглера: особливості та точні оптимальні розв'язки. Праці з прикладної математики і механіки. 2011. Вип. 11(1), С. 717718.

14. Ніколов С., Недев В. Біфуркаційний аналіз і динамічна поведінка перевернутого маятника 3 обмеженим контролем. Журнал теоретичної та прикладної механіки. Софія, 2016. Вип. 46(1), С. 17-32. $632 \mathrm{c}$.

15. Кузнєцов Ю. А. Елементи прикладної теорії біфуркацій. Нью-Йорк, Springer-Verlag, 2013.

\section{В. В. Ковальчук, к. ф.--м.н, доцент}

(доцент кафедри «Теоретична і прикладна механіка», Держсавний університет інфраструктури та технологій)

\section{БІФУРКАЦІЙНИЙ АНАЛІЗ СТІЙКОСТІ ОДНІЕЇ ДИНАМІЧНОЇ СИСТЕМИ ЗІ СЛІДКУЮЧОЮ СИЛОЮ}

У даній роботі для перевернутого подвійного маятника з асиметричною слідкуючою силою побудована математична модель в узагальнених координатах. Динаміка системи досліджується аналітичними і числовими методами. Наведені діаграми стійкості. Проаналізований вплив параметрів слідкуючої сили на динамічну поведінку маятника. Для отримання інтегральних кривих $i$ фазових портретів застосовується чисельне моделювання. Також побудовані траєкторії нижнього і верхнього полюсів маятника.

Маятникові системи є об'єктом дослідження багатьох сучасних науковиів. Модель перевернутого багатоланкового маятника активно застосовується для дослідження та експериментів у таких наукових галузях як проектування автоматичної системи посадки літаків, двоходових локомотивних мамин, в робототехніці, аерокосмічній галузі та ін. Перевернутий маятник зі слідкуючою силою, що є об'єктом даного дослідження, може імітувати конструктивні елементи опор залізничних мостів чи інших споруд, колієукладальних зводів, гусеничних машин та інших конструкиій.

Розглянутий у иій роботі перевернутий дволанковий маятник, верхній кінещь якого пружно-закріплений $i$ перебуває під дією слідкуючої сили, є прикладом нелінійної та нестабільної динамічної системи. При дослідженні динаміки таких механічних систем з неконсервативними позиційними силами велику увагу приділяють вирішенню проблем стійкості, щзо виникають при проектуванні конструктивних елементів у зазначених вище промислових галузях. Наявність слідкуючої сили підсилює динамічну нестійкість системи. У иій роботі показано, щу поступова зміна суттєвих параметрів системи може призвести до біфуркаиій у фазовому просторі маятника. При переході значень указаних параметрів через біфуркачійні значення відбуваються якісні зміни у поведінці системи.

Ключові слова: динамічна система, перевернутий подвійний маятник, слідкуюча сила, стійкість.

Збірник наукових праць ДУІТ. Серія «Транспортні системи і технологї̈», 2019. Вип.33. Т.2 
В. В. Ковальчук, к. ф.-м.н, доцент

(доцент кафедры "Теоретическая и прикладная механика",

Государственный университет инфраструктуры и технологий)

\section{БИФУРКАЦІОННЫЙ АНАЛИЗ УСТОЙЧИВОСТИ ОДНОЙ ДИНАМИЧЕСКОЙ СИСТЕМЫ СО СЛЕДЯЩЕЙ СИЛОЙ}

В данной работе для перевернутого двойного маятника с асимметричной следящей силой построена математическая модель в обобщенных координатах. Динамика системы исследуется аналитическими и числовыми методами. Приведены диаграммы устойчивости. Проведен анализ влияние параметров следящей силь на динамическое поведение маятника. Для построения интегральных кривых $u$ фазовых портретов применяется численное моделирование. Также построены траектории нижнего и верхнего полюсов маятника.

Ключевые слова: динамическая система, перевернутый двойной маятник, следящая сила, устойчивость.

Збірник наукових праць ДУІТ. Серія «Транспортні системи і технологї̈, 2019. Вип.33. Т.2 